\title{
СОЦИАЛЬНЫЙ АСПЕКТ СИМВОЛА ЗРЕНИЯ В АРХАИЧЕСКОЙ КУЛЬТУРЕ
}

\section{Ю.Г. Писаренко}

«Зрение»- один из наиболее интересньх и фундаментальных культурных символов в истории мышления ${ }^{1}$. В частности, начиная с эпохи первобытности, категории «видимого» и «невидимого»естественным образом стали основополагающими в осознании социальных явлений - родства, собственности, власти. В данной публикации, реконструируя историю одного магического заговора, попытаемся показать насколько социально осмысливалась функция «зрения» в архаическом обществе.

В сборнике великорусских заклинаний Л.Н.Майкова, в рубрике «Отношения общественные» под № 337 помещен заговор «На царские очи». Записанный С. Огородниковым в с. Соломбала Архангельской губ. он был впервые опубликован в Памятной книге этой губернии за 1865 г., но, несомненно, восходит к более раннему времени. Вот его текст: «Господи, благослови! Как утренняя заря размыкается, Божий свет разсветается, звери из пещеры, из берлог выбираются, птицы с гнезд солетаются, - так бы раб Божий (имя рек) ото сна пробуждался, утренней зарей умывался, вечерней зарей утирался, красным солнцем одевался, светлым месяцем подпоясался, частыми звездами подтыкался. Покорюсь и помолюсь: „Вы же, кормилицы, иарские очи, как служили царям-царевичам, королям-королевичам, так послужите рабу Божию (имя рек), день послужите и в ночь послужите, по утру рано и в вечеру поздно, в каждый час, в каждую минуту, век по веку,

\footnotetext{
${ }^{1}$ Голосовкер Я.Э. Логика мифа.-М., 1987.-С. 50-61; Крымский С.Б., Парахонский Б.А., Мейзерский В.М. Эпистемология культуры. - К., 1993. - С. 125-136.
}

Актуальні проблеми духовності:

зб. наук. праць / Ред.: Я.В. Шрамко

Вип. 10. - Кривий Ріг, 2009, 302-312 
отныне до веку. Ключ и замок словам моим“» 2 .

Формально это заклинание, «лишавшее» царя очей, могло бы подпадать под действие статьи I главы 2 «Соборного Уложения» 1649 г. Алексея Михайловича, где говорится о преступлениях против Величества (чести и здравия Царя). Согласно Г.Г. Тельбергу, зафиксированная здесь вина «будет кто каким умышлением учнет мыслити на Государское здоровье злое дело» ${ }^{3}$, предполагавшая казнь смертью, на самом деле подразумевала колдовство ${ }^{4}$.

Горделивое желание обладать «царскими очами» встречается также в следующем заговоре, № 338 (из той же Арханг. губ.) «На подход ко властям или на умилостивление судей». Здесь образ «царских очей», превратившихся в «ясное око волка», содержит идею независимости, устрашения, - качеств, необходимых, чтобы противостоять властям в суде. При этом «очи» ставятся в один ряд $\mathrm{c}$ «речами царскими» и «царской грозой» 5 , что, как бы, лишает этот признак монаршего достоинства исключительности. В первом же заклинании роль «царских очей» не только эксклюзивна, но и, с современной точки зрения, оригинальна. Судя по их прозвищу «кормилицы», очи царя должны обеспечить «рабу Божьему», как и своему прежнему хозяину ${ }^{6}$, благосостояние. Компактное по форме и законченное по содержанию, заклинание рождает ряд интересных вопросов, которых коснемся в настоящей работе. Среди них такие: откуда пошло название очей «кормилицы» и почему это - очи царя? Насколько «заимствование» очей царя было обосновано с точки зрения архаического мировоззрения и было ли символически закреплено в каком-либо ритуале? Соответственно, чем на самом деле могло обернуться подобное «ослепление» для царя? И, наконец, что нового узнаем мы о феномене власти?

Представление об очах как «кормильцах», напоминающее современные метафоры «сытых» и «голодных» глаз, имеет давние истоки. Так, в одной из древнейших индийских упанишад, Брихадараньяка Упанишаде (VII-VI вв. до н.э.?) о полноправном члене общества, муже, говорится: «глаз - его мирское богатство, ибо глазом он добывает

\footnotetext{
${ }^{2}$ Майков Л.Н. Великорусские заклинания // Записки Имп. Рус. геогр. Общества по отд. этнографии. - СПб., 1869. - Т. 2. - С. 562.

${ }^{3}$ Соборное Уложение царя Алексея Михайловича 1649 года // Памятники русского права. - Вып. VI. - М., 1957. - С. 28.

${ }^{4}$ Райан В.Ф. Баня в полночь: Исторический обзор магии и гаданий в России / Пер. с англ. - М., 2006.-С.613.

${ }^{5}$ Майков Л.Н. Указ. соч. - С.563-564.

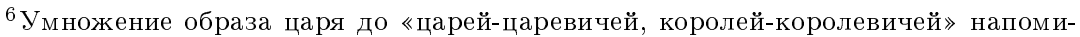
нает хорошо известные фольклорные образцы.
} 
его» ${ }^{7}$. Логика здесь своеобразна: «приобретать» богатство - это значит его «видеть», а то, чем «видят (-приобретают)», само превращается в «видимое (-приобретаемое)». Субъект сливается с объектом.

Реальным богатством для современников упомянутой Упанишады был, прежде всего, скот. В термине «скотъ» понятие богатства суммировалось и в древней Руси. Именно в традиции скотоводов слияние представлений о «зрении» и «владении» прослеживается этнографами вплоть до XX в. Например, когда европеец (в начале XX в.) просит самоеда-юрака продать одного из принадлежащих ему трех тысяч оленей, тот отказывается, аргументируя это таким образом: «- Олени ходят, я на них смотрю, а деньги спрячешь - не видно...» ${ }^{8}$. Владеть чем-либо значит обязательно это видеть. Причем ненарушение зрительной картины обеспечивает целостность «Я» самого человека. Стадо «образует», «ожизнествляет» «Я» человека, через посредство зрения последнего.

О богатых казахских собственниках скота начала XIX в. А.И. Левшин писал: «Однажды спросил я одного владельца восьми тысяч лошадей, почему он не продает ежегодно по некоторой части табунов своих. Он отвечал мне: ,Для чего стану я продавать мое удовольствие? Деньги мне не нужны: я должен запереть их в сундук, где никто не увидит их. Но теперь, когда табуны мои ходят по степям, всякий смотрит на них, всякий знает, что они мои, всякий говорит, что я богат“» ${ }^{9}$. Несмотря на то, что здесь силен момент тщеславия, на первом месте остается удовольствие от созерцания своих лошадей.

Аналогично, в разговоре путешественника В. Тарасова (начало XX в.) с самоедом о возможности продажи тем мяса своих оленей, тот отвечает: «Зачем нам много денег? Много денег не нужно: их никто не видит, и их легко можно потерять, а еще легче пропить; оленей же все видят и знают, что я богат» ${ }^{10}$. Можно было бы заподозрить, что мотивировка отказа от продажи исчерпывается соображениями престижа, мнения посторонних, а не личной связью между хозяином и стадом, если бы не следующее замечание того же автора: «Некоторые - даже владельцы больших стад - на мясо для себя предпочитают купить оле-

\footnotetext{
${ }^{7}$ Брихадаранъяка Упанишада // Памятники л-ры народов Востока. Переводы. V.- М., 1964. - С. 77.

${ }^{8}$ Максимов А.Н. Скотоводство малокультурных народов //Максимов А.Н. Избранные труды. - М., 1997.-С. 257.

${ }^{9}$ там же. - С. 259.

10 Там же. - С. 257.
} 
ней где-нибудь» ${ }^{11}$. Следовательно, оленевод избегает убийства животных именно своего стада, очевидно, стараясь сохранить некую личностную связь «хозяин-стадо». Поэтому ссылка на зависть окружающих кажется аргументом вторичным.

Смысл такого «любительского» разведения скота в полной мере понять сложно. Но здесь явно борются две тенденции: наличие стремления к престижу, казалось бы, позволяет говорить о появлении в недрах прежнего рода обособленного хозяина-собственника, но, при этом, так называемая «собственность» сама довлеет над ним, подобно роду. Это отношение к скоту как к «трансцендентной ценности» (термин А.Я. Гуревича) еще сохраняет в себе черты тотемизма. Представление о «владении» как «видении», а не как «обладании» ${ }^{12}$, очевидно, характерно для пограничной стадии появления «индивидуального» из «родового». Такая же двойственность была отмечена Ю.П. Аверкиевой в индейском потлаче - обычае одаривания и устройства пиров. Широко известный как институт, закрепляющий престиж богатых, он зарождался для того, чтобы выравнивать имущественное неравенство ${ }^{13}$.

В рассмотренных нами примерах «Я» в полной мере не обособилось от окружающего мира, оно состоит в воспринимаемой человеком зрительной картине. «Владеть» для него значит «видеть» и «быть» одновременно. При этом он считает для себя престижным, чтобы в этом «видимом» собралось возможно больше «трансцендентной» ценности данного общества, - в приведенном случае-скота, благодаря чему, он, как бы, сам приобретает значение прежнего коллективного тотема, а значит и авторитет. Поэтому он избегает терять животных своего стада, практически, за одним исключением, когда подобная жертва выделяется на обязательное поддержание старых или образование новых социальных связей - дар, прием почетного гостя и т. п. ${ }^{14}$. Бо́льшая щедрость (демонстрация обильности), в особенности не получавшая возмещения, давала дарителю более высокое положение, а со временем - и власть над сородичами ${ }^{15}$.

Выразительное представление о глазах как символическом эквива-

\footnotetext{
${ }^{11}$ там же.

${ }^{12} \mathrm{Cp}$. Фромм Э. Иметь или быть? // Фромм Э. Величие и ограниченность теории Фрейда. - М., 2000. - С. 214-218.

${ }^{13}$ А веркиева Ю.П. Разложение родовой общины и формирование раннеклассовых отношений в обществе индейцев Северо-западного побережья Северной Америки. - М., 1961.-С. 35, 115 и др.

${ }^{14}$ Максимов А.Н. Указ. соч.-С. 257, 261-262.

${ }^{15}$ Хазанов А.М. Социальная история скифов (Основные проблемы развития древних кочевников Евразийских степей). - М., 1975. - С. 184.
} 
ленте «богатства», встречаем в произведении античного автора II в.н.э. Лукиана Самосатского «Токсарид, или Дружба» ${ }^{16}$, где, в частности, рассказывается о двух скифах, которые, в знак заключения дружеского союза, по обычаю, выпили вина, смешанного с кровью друг друга. Когда же, во время нападения савроматов, один из них был пленен, другой, переплыв реку, добровольно пришел во вражеский стан, будто бы для того, чтобы выкупить друга, о чем заранее известил, выкрикнув слово «Зирин!». «Того, кто произнесет это слово,-поясняется в рассказе,- савроматы не убивают, но задерживают, считая, что он пришел для выкупа». Поскольку у скифа, на самом деле, никакого имущества при себе не было (его разграбили во время нападения), он предложил начальнику савроматов себя в обмен на свободу друга. На это савромат возразил: «Невозможно задержать тебя всего, раз ты пришел, говоря: „Зирин“; оставь нам часть того, чем обладаешь, и уведи своего друга». Он пожелал взять у скифа глаза, что и послужило выкупом. Позже вызволенный таким образом друг также себя ослепил, и оба незрячих стали кормиться за общественный счет скифского племени (Toxaris. 39-41).

В этом рассказе, согласно пояснению савромата, существо процедуры «зирин» не в качественной характеристике выкупа, а в его соответствии общепринятой пропорции всего «имущества-существа-тела» хозяина, участника обмена, то есть - его части. Будучи видимой для самого человека, эта доля собственности, именно через зрение, выступает «телесной частью» своего владельца, следовательно, сохраняет личностные характеристики последнего. Во время обмена («зирин») с другим, эта частичка сначала утрачивается, становится невидимой, и вместе с ней будто бы символически «умирает» (слепнет) сам человек, потом его жизнь и зрение восстанавливаются также символически через обмен на телесную-видимую часть контрагента ${ }^{17}$. При отсутствии у скифа богатства, как его видимой-телесной частицы, этап его символической «невидимости-смерти», присущий договору «зирин», мог осуществиться лишь через утрату им глаз. Их «заменил» выкупленный из неволи друг, ставший к тому времени частью «тела-имущества» савромата.

Последний случай наиболее ярко демонстрирует, что функция «ви-

\footnotetext{
16 Лукиан. Собрание соч.: в 2-х т. - М., 1935.- Т. 1. - С. 310-312.

${ }^{17}$ Такой «круговорот» объясняет и само название «зирин», очевидно, родственное осетинскому zyryn:zyryd / zurun:zurd - 'кружить(ся)', 'вертеть(ся)' (Абаев В.И. Историко-этимологический словарь осетинского языка. - Л., 1989. - T. IV.C. 324).
} 
дения» (или «зрение», «глаза») приобрела семантику «социального»в человеке - индикатора его включенности в окружающий мир, факта его существования, наиболее распространенным проявлением чего выступают его имущественные отношения. Пример с ослеплением скифа показывает, что любая задействованная в обмене вещь является частичкой своего собственника именно через глаза, поэтому они даже могут символически заменить потерянную вещь во время обмена ${ }^{18}$.

Приведенный сюжет интересен не только тем, что в нем глаза являются эквивалентом собственности, но и - друга. Как, в свое время, показал В.Я.Пропп, «свой»- это всегда «видимый» и «видящий», тогда, как «чужой» (в частности, происходящий из «иного», загробного мира) - «невидимый» и «невидящий» ${ }^{19}$. Вывод о том, что в древнейшем понимании «родство» и означало «видимость», следует также из наблюдения Н.В. Калачова о том, что «по первоначальным понятиям славян жить (гоить) в смысле общественного бытия, значило находиться постоянно в роде, принадлежать к нему, как неотдельный член его, оставаться навсегда вместе с своими родичами» ${ }^{20}$. Поэтому, понятие «изгойства» ассоциировалось, прежде всего, с территориальным удалением из рода, то есть - из зоны «видимости».

О том, что «зрение» могло расцениваться как неотъемлемый признак рода, говорит ослепление Василька Теребовльского $(1097 \text { г. })^{21}$. Провозглашенное Мономахом как травма рода («вверженъ в ны ножь»), со стороны ослепителей - Давыда и Святополка - оно выглядит как наказание за посягательство на братский удел. Столкновение двух трактовок только подтверждает, что «зрение» человека - это признак его принадлежности к роду, притом неразрывный с причастием в его имущественном выражении. Неслучайно, княжеский съезд в Уветичах 1100 г. уже, как прежде, не находит нужным выделять калеке отдельную волость, и дает братьям - Володарю и Васильку один на двоих Перемышль, явно указывая на неполноправие Василька следующей ремаркой: «Да аще вам любо, да седита, аще ли ни,- да пусти Василка семо, да его кормим сде» ${ }^{22}$. Очевидно, согласно традиционному

\footnotetext{
${ }^{18}$ Подробнее: Писаренко Ю.Г. Договір «зірін»у Лукіана Самосатського. Семіотичний аналіз //Східний світ. - К., 2004. - Вип. 2. - С. 68-77.

${ }^{19}$ Пропп В.Я. Исторические корни волшебной сказки. - Л., 1986. - С. 72.

${ }^{20}$ Калачов H.В. О значении изгоев и состоянии изгойства в Древней Руси $/ / \mathrm{Ap}-$ хив историко-юрид. сведений, относящихся до России, изд. Ник. Калачовым.СПб., 1876. - Кн. 1.- С. 56.

${ }^{21}$ Писаренко Ю. Ослепление Василька Теребовльского (1097 г.). Мифологический подтекст // Соціум. - К., 2003. - Вип. 3. - С. 179-196.

22 Повестъ временных лет. - М.-Л., 1950.- Ч. 1 (далее-ПВЛ). - С. 181.
} 
восприятию, отсутствие зрения заведомо исключало причастие, как в смысле владельческих, так и как таковых родственных прав. Вернее было бы сказать: «слепота» и была «отсутствием причастия», равно как «отсутствие причастия» означало «слепоту».

В последнем случае княжеский род берется нами как модель рода вообще. И мы видим, что понятие об «очах-кормильцах» восходит к пониманию «рода» и «причастия» как «видения». Истоки же особой выделенности в качестве источника благодати «царских очей» исторически ближе к первому из приведенных нами примеров, где из группы скотоводов постепенно выделяются более состоятельные и авторитетные лица, способные на щедрый дар и этим исподволь добивающиеся большего, а позже и исключительного, влияния - то есть власти ${ }^{23}$. При этом, на прирожденное право причастия рядового члена коллектива постепенно накладывается и зависимость от лидера («царя») не просто как верховного распорядителя общественной собственности, но и - от «приобретенных» им в связи с этим сакральных качеств «благодатного начала» ${ }^{24}$. Воплощением такового и выступали «очи царя».

В чем же мог выражаться желаемый «переход» к человеку «царских очей»? Естественно, о непосредственном заполучении глаз царя речи идти не могло. Но возможны два других варианта. Например, это могло означать воображаемый переход «волшебного свойства» царских очей «притягивать», «концентрировать» благосостояние. Однако, подобная мечта, думаем, не исключала и более конкретного случая. Пример с договором «зирин», в котором глаза заменили собой «богатство», подсказывает нам, что, когда речь заходила о заимствовании «царских очей», их символическим выражением могли стать некие царские богатства, в частности - деньги.

В источниках о московской придворной жизни XVI-XVII вв. то и дело упоминается о том, как важно для подданных «видеть светлые царские очи». Это милость. И впавшему в немилость видеть «очи царя» не дозволялось ${ }^{25}$. Если вообе глаз считается наиболее «солнечным» органом, то для князя либо царя это-средоточие его специ-

\footnotetext{
${ }^{23}$ Хазанов А.М. Указ. соч.-С. 183 ; Васильев Л.С. Феномен власти-собственности (К проблеме типологии докапиталистических структур) //Типы общественных отношений на Востоке в средние века. - М., 1982.-C. 68-69.

${ }^{24}$ Васильев Л.С. Указ. соч.-С. 80.

${ }^{25}$ Котошихин Гр. О России в царствование Алексея Михайловича.-СПб., 1906. - Изд. 4-е. - С. 45; Горсей Д. Записки о России. XVI - начало XVII в. - M. 1990.-С.89; Забелин И. Домашний быт русских царей в XVI и XVII ст.-M., 1862. - Ч. 1. - С.291. Характерно, что в словосочетании «видеть царские очи», как и в рассматриваемом заговоре, сторона царя выступает в роли объекта.
} 
альной «солнечной» функции. Она, отчасти, поясняется из роли богадаятеля, приписываемой самому Даждьбогу-Солнцу, внуком которого, согласно «Слову о полку Игореве», и был русский князь. А.П. Толочко, на наш взгляд, правильно подметил, что понятие «света», в связи с образом князя, не только указывает на какую-то мистическую благодать, нисходящую с него на подданных, но и прямо «материализуется» в демонстративных раздачах милостыни («показывании» милости), из которых автор указывает на обязательные посмертные раздачи княжего «добра» народу ${ }^{26}$. Так, Святополк Окаянный, заняв киевский стол после смерти отца, Владимира, «созвавъ люди, нача даяти овемъ корзна, а другым кунами, и раздая множьство» 27 . Здесь хотелось бы добавить отмечаемые летописью прижизненные пиры и пожертвования князем Владимиром, который неизменно величается в былинах «Красным Солнышком». Кажущаяся преувеличенной летописцем, щедрость князя много веков спустя находит подтверждение в действиях московских царей. Обильные раздачи ими денег и других материальных благ всем членам общества, вплоть до тюремных сидельцев, сопровождали как большие события в жизни самого государя (рождение, свадьба, смерть), так и крупнейшие праздники ${ }^{28}$. Очевидно, подобные одаривания материально подкрепляли магическое воздействие самих «царских очей».

Одним из случаев, с которым можно было бы связать «волшебное» заимствование «очей царя», представляется тот, в котором обычный муж целиком легитимно выступал в княжеской или царской роли, т. е. - во время женитьбы ${ }^{29}$.

Украинская свадебная песня упоминает о соперничестве князя-жениха с Солнцем-Дажбогом: «- Ой ти, боже, ти Дажбоже, рано-рано,/ Зверни ж мені з доріженьки, ранесенько,/ Бо ти богом рік від року, рано-рано, / [...] А я князем раз на віку, ранесенько...» ${ }^{30}$. Речь идет о попытке сбить божество с дороги - своеобразном «ослеплении». Князь-жених, актуализуя общественно значимую идею «плодородия»,

${ }^{26}$ Толочко О. Образ держави і культ володаря в давній Русі // Mediaevalia Ucrainica: ментальність та історія ідей. - К., 1994. - Т. III. - С. 32-34. В частности, автор ссылается на Даниила Заточника.

${ }^{27}$ ПВЛ. - С. 95.

${ }^{28}$ Там же.-С. 86; Котошихин Гр. Указ. соч.-С.13-14, 15-16, 20-21; Забелин И. Указ. соч. - С. 305-310 и др.

29 A pxuепископ Вениамин. Новая Скрижаль. /Новый рус. перевод с 9-го изд. К. К-го.- СПб., без г. - С. 432.

${ }^{30}$ Цит. по: Топоров В.Н. Об иранском элементе в русской духовной культуре // Славянский и балканский фольклор. - М., 1989.-С. 39. 
временно наделяется функцией, обычно приписываемой Солнцу и сакральному главе коллектива - князю (царю).

О приобретении в данной ситуации «царских очей» косвенно свидетельствует пример вступления в совершеннолетие, брачный возраст (15 лет) самих царевичей. Согласно Гр. Котошихину (середина XVII в.), их до этих пор «окроме бояр и ближних людей, видети никто не может». Даже пребывая в церкви, царевичи (и царевны) были завешены тафтою. И только с наступлением 15-летия, «как уведают люди, что уж его (т.е. царевича. - Ю.П.) объявили, и изо многих городов люди на дивовище ездят смотрити его нарочно» ${ }^{31}$. Очевидно, невидимый прежде царевич, окруженный лишь своими кормильцами ${ }^{32}$, и сам будто бы обретал ранее невидимый и неведомый для него мир. В соответствии с реконструкцией архаичной схемы наследования, когда брак закреплял приход к власти, а последний предполагал смещение (убийство) прежнего царя, это бы и означало символический «переход» очей от умирающего к живому. При этом нужно учесть, что получение власти сыном от отца - более новая форма наследования, чем зятем от тестя. Перенесение прежнего, традиционного понимания на новые условия могло породить в фольклоре конфликтную ситуацию, вроде отцеубийства, инцеста и раскаяния Эдипа, опять-таки, сопровождавшегося ослеплением ${ }^{33}$. «Зрение-власть», приемлемая в одной ситуации, в другой понималась как грех и требовала аннулирования.

Помимо внешней борьбы за трон или его наследования, существенно и «внутреннее» содержание власти, состоящее во взаимосвязи правителя и подданных. Причем, как, например, считал Р. Каюа, именно санкция со стороны последних, а не безусловная воля монарха, поясняет природу власти ${ }^{34}$. Скорее всего, здесь и коренится основа претензии простого смертного на «царские очи». Отголоски этого первоначального феномена, согласно которому возвышение фигуры властителя зиждется на доброй воле народа, кажется, как нельзя более рельефно проявляются в легитимной практике посмертного ограбления правителей (светских и церковных). Обычай европейского Средневековья, который под названием «сполиирование» ${ }^{35}$ недавно развернуто опи-

\footnotetext{
${ }^{31}$ Котошихин Гр. Указ. соч. - С. 17.

${ }^{32}$ См. Гарданов B.K. «Кормильство» в древней Руси (К вопросу о пережитках родового строя в феодальной Руси IX-XIII вв.) // Советская этнография.-М., 1959. - № 6. - С. 53 .

${ }^{33}$ Пропn В.Я. Указ. соч. - С. 332-336.

${ }^{34}$ Каюа Р. Людина та сакральне. - К., 2003. - С. 117.

${ }^{35}$ От лат. spolio - снимать одежду, раздевать, обдирать, похищать, лишать.
} 
сал М.А.Бойцов, впервые в киево-русской историографии был затронут И.Я. Фрояновым ${ }^{36}$. Смерть и, подчеркнем, в силу этого - утрата зрения правителем, на фоне временно воцарившейся анархии, сопровождалась полным разграблением его имущества. По-видимому, замена такого грабежа более цивилизованными формами сказалась в еще прижизненной раздаче умирающим князем своих богатств либо жев жертвовании наследниками покойного щедрой милостыни ${ }^{37}$. Как мы видели на примере княжеского рода Рюриковичей, в случае ослепления члена рода (Василька) или же-его смерти («ослепления»), его имущество возвращалось в фонд рода, минуя наследников ${ }^{38}$. Очевидно, в публичном ограблении монарха сказывается влияние того же «родового» института, только «родом» ощущает себя весь народ.

И.Я.Фроянов, уловив в посмертных ограблениях князей, в частности - Юрия Долгорукого и Андрея Боголюбского,- мотивы первобытной психологии, обратился к материалам этнологов, фиксирующим аналогичные посмертные грабежи. Так, у индейцев-коневодов общинники, узнав о смерти богатого сородича, бросались к его табуну и захватывали лучших коней, пренебрегая завещанием умершего и ничего не оставляя его вдове и детям. Интересно, что с особым рвением грабилось имущество скупых богачей ${ }^{39}$. По замечанию Ю.П. Аверкиевой, богатства считались собственностью индейца, пока он их собирал, а когда были накоплены, начинали рассматриваться как собственность общества ${ }^{40}$. Факт смерти, очевидно, наиболее наглядно подтверждал, что богатство накоплено. Вначале статьи мы рассказали о собственниках стад, глаза которых «наполнялись» их скотом. Скупой богач, «зрячий» в окружении своего стада, мог бы казаться «слепым» внешнему, родовому окружению. Хотя его имущество и считалось потенциально родовым, он избегал его демонстрации и раздаривания ${ }^{41}$, оставаясь «вещью в себе». Замкнутый для социума, он будто «умер-

\footnotetext{
${ }^{36}$ Бойцов М.A. Ограбление мертвых государей как всеобщее увлечение // Казус 2002.- М., 2002.- Вып. 4.-С. 137-191; Фроянов И.Я. Киевская Русь. Очерки социально-политической истории. - Л., 1980.-С. 144-146.

37 Фроянов И.Я. Указ. соч. - С. 144. В особенности, впечатляет летописный рассказ о предсмертном раздаривании богатств Владимиром Васильковичем (под 1288 г.) (Ипатьевская летопись (Полн. собр. рус. лет. Т. ІІ). - 2-е изд.-М., 2001.Стб. 914).

${ }^{38}$ Толочко А.П. Князь в Древней Руси: власть, собственность, идеология. - К., 1992.- C. $24-25$.

39 Фроянов И.Я. Указ. соч.-С. $145 ;$ Аверкиева Ю.П. Индейцы Северной Америки. - М., 1974.-С. 266.

${ }^{40}$ Аверкиева Ю.П. Разложение родовой общины. . - С. $35,115$.

${ }^{41}$ Там же. - С. 35.
} 
ослеп» еще при жизни, став препятствием, «темницей» для развития коллективного блага. Очевидно, близок к этому и смысл «слепоты» греческого бога богатства Плутоса, которого связывают с загробным миром $^{42}$. Воплощение «богатства» в его абсолюте, как замкнутого в себе, неделимого «целого», противоположного привычному родовому «причастию», ассоциируется с «незрячестью-смертью».

Согласно традиционным взглядам, князь (царь) щедрыми прижизненными раздачами и явлением своих «светлых очей» магически равномерно стимулировал витальные силы народа. С наступлением же его смерти, «потерей зрения», над подданными будто бы нависала угроза его превращения в «вещь в себе». Разомкнуть его как темницу, заполучив то добро, которое прежде «наполняло» его через очи и сохранило на себе печать его «света-милости», кажется, и входило в задачу всенародных грабежей.

Возможно, с мотивом наступившей «слепоты-смерти» монарха, который уподоблялся Солнцу, связана и практика ночного погребения правителей. Ранее объясненное нами боязнью сполий ночное «потаение» тела Владимира $(1015 \text { г. })^{43}$, находит параллель в обычае погребения ночью московских царей. Согласно Гр. Котошихину, эти похороны сопровождались повальными грабежами и убийствами. Своего рода магической стимуляцией возрождения «света» вслед за ночью, ассоциировавшейся со «смертью-слепотой» «Солнце»-царя, могло быть проводившееся тогда освобождение из тюрем преступников ${ }^{44}$. Очевидно, дабы избежать ограбления самого правителя, как после смерти Владимира и других князей, так и при проводах московских царей, раздавалась щедрая погребальная милостыня ${ }^{45}$.

Ко времени своей письменной фиксации (середина XIX в.) пожелание «царских очей, кормилиц» приобрело сугубо виртуальный характер, но его истоки, думаем, восходят к ритуалам типа сполиирования, реально связанным с «потерей зрения» царем. Тогда каждый, сумевший добыть частичку имущества властителя, верил, что заполучил «очи царя», а они, в свою очередь, «возрождались» во взошедшем на трон наследнике.

\footnotetext{
42 Фрейденберг О.М. Слепец над обрывом // Язык и литература.-Л., 1932.T. VIII. - C. $229-244$.

${ }^{43}$ Писаренко Ю. Почему «потаиша» смерть князя Владимира (К летописной статье 1015 г.) // Ruthenica.-К., 2006.-Вип. 5.-С. 238-248; Писаренко Ю. К поиску смысла посмертного ограбления правителей // Український історичний збірник. К., 2007.- Вип. 10.- С.9-14.

${ }_{44}^{4}$ Котошихин Гр. Указ. соч. - С. 21.

${ }^{45}$ Там же.
} 